\title{
The Location of Bacterial Antigens on Sections of Bacillus cereus by Use of the Soluble Peroxidase-Anti-peroxidase Complex and Unlabelled Antibody
}

\author{
By J. A. SHORT AND P. D. WALKER \\ Department of Bacteriology, Wellcome Research Laboratories, \\ Beckenham BR3 3BS, Kent
}

(Received 29 November 1974; revised Io January 1975)

\begin{abstract}
SUMMARY
The location of antigens on sections of bacteria using the soluble peroxidaseanti-peroxidase complex in conjunction with unlabelled antibody is described. Using this technique, spore antigens have been detected in the cytoplasm of vegetative cells during forespore septum formation and subsequent stages of sporulation. Antigenic sites were first associated with poly-beta-hydroxybutyric acid granules and subsequently were found in increasing quantities in the cytoplasm of the sporangium. Vegetative cell antigens were located on the cell wall and in the cortical region during sporulation. During germination antigens were located in the cortical region, and during outgrowth on the cell wall. These findings are discussed in the light of existing biochemical data.
\end{abstract}

\section{INTRODUCTION}

Distinct antigenic differences between the vegetative cells of spore-forming bacteria and the spores they produce have been demonstrated using labelled antibody techniques. These differences were first demonstrated with the light microscope using fluorescent labelled antibodies (Walker \& Batty, 1964, 1965) and were later extended in electron microscopic studies using ferritin-labelled antibodies (Walker et al. 1966; Walker, Thomson \& Baillie, 1967; Walker \& Thomson, 1972). Unfortunately, due to the non-specific attraction of ferritin for all conventional embedding media used in electron microscopy, observations with ferritin-labelled antibody are largely confined to pre-embedding staining. The technique is thus limited to a study of surface antigens, and internal antigenic sites can only be located if some method of facilitating penetration of the labelled antibody, such as partial disintegration, is used.

In an effort to overcome the difficulties inherent with ferritin-labelled antibodies, enzymelabelled antibodies were introduced by Avrameas \& Uriel (1966), Avrameas (1969) and Nakane \& Pierce $(1967 a, b)$. Partial success in locating bacterial antigens on sections of formaldehyde-fixed pre-polymerized methacrylate embedded material were reported by Walker, Thomson \& Short (197I). Non-specific staining of the embedding media was overcome but, in general, the method did not give consistently reliable results.

The lack of consistency and reliability of results obtained from using antibodies labelled directly with markers probably results from the reduced sensitivity caused by inactivation of the antibody during labelling. In this respect the use of unlabelled antibodies should therefore be a considerable advantage, and methods using either normal or hybrid anti- 
bodies have been described (Sternberger \& Cuculis, 1969; Hämmerling et al. 1968; Mason et al. 1969).

Sternberger et al. (1970) introduced the use of the soluble peroxidase-anti-peroxidase (PAP) complex in conjunction with unlabelled antibodies. Moriarty \& Halmi (1972) used this technique to demonstrate the antigenic sites of adrenocorticotropin cells using electron microscope studies. Hinton et al. (1973), Moriarty, Moriarty \& Sternberger (1973) and Petrali et al. (1974) have shown that the technique is extremely sensitive.

We describe the results of the application of this technique in locating bacterial antigens on sections, by reference to the location of spore and vegetative antigens during sporulation and germination.

\section{METHODS}

Organism. The organism used was Bacillus cereus var. terminalis.

Growth and processing for electron microscopy. Cells at various stages of sporulation and germination were prepared as described by Baillie et al. (1967). Samples were removed at appropriate intervals and processed for electron microscopy using the fixation and embedding procedure of Walker (1969).

Immunochemical staining. Appropriate sections, approximately $70 \mathrm{~nm}$ thick, were cut on an LKB Ultratome and mounted on 200 mesh Formvar-coated copper or nickel grids. The grids were immersed in small amounts of the staining solutions and after exposure to each were washed in tris-buffered saline $(5.0 \mathrm{M}$-tris buffer adjusted to $\mathrm{pH} 7.6$ with $\mathrm{I} \mathrm{M}-\mathrm{HCl}$ and then diluted r : ro with physiological saline). All staining solutions were diluted with trisbuffered saline containing $0.1 \%$ gelatin.

Using sections of material embedded in glycol methacrylate it was unnecessary to facilitate staining by prior etching of the sections with hydrogen peroxide or to pre-treat sections with normal serum to prevent non-specific staining. However, before staining, the surface of the grids was wetted by immersion in a drop of tris-buffered saline. The grids were then transferred to drops of various dilutions $(\mathrm{I}: 20 ; \mathrm{I}: 2000)$ of the specific antiserum and left at room temperature, unless the incubation time was to exceed $\mathrm{I} h$, when incubation was carried out at $4{ }^{\circ} \mathrm{C}$. All grids incubated at $4{ }^{\circ} \mathrm{C}$ were allowed to equilibrate to room temperature for 30 min before proceeding with subsequent steps.

The grids were next placed in drops of donkey anti-rabbit IgG (see below) diluted I : Io for $5 \mathrm{~min}$, and finally placed for $5 \mathrm{~min}$ in a solution consisting of a drop of the PAP complex.

The grids were then transferred to a solution of the substrate. The peroxidase substrate used was 3,3-diaminobenzidine (DAB; Koch Light) and hydrogen peroxide (BDH). The reaction mixture, which was made up immediately before use, consisted of $22 \mathrm{mg} D \mathrm{DAB}$ in $170 \mathrm{ml}$ of $0.5 \mathrm{M}$-tris buffer $\mathrm{pH} 7.6$, and $\mathrm{I}^{\circ} 5 \mathrm{ml}$ of $0.3 \%$ solution of $\mathrm{H}_{2} \mathrm{O}_{2}$ made up from a $30 \%$ stock kept at $4{ }^{\circ} \mathrm{C}$. Before use the solution was filtered through two thicknesses of filter paper. To prevent non-specific adsorption to the embedding medium, the DAB- $\mathrm{H}_{2} \mathrm{O}_{2}$ mixture was agitated (Kawarai \& Nakane, 1970) with a magnetic stirrer. The grids were clamped in forceps and immersed in the moving solution for approximately 3 min by means of a simple ring stand.

After treatment in the reaction mixture, the grids were thoroughly washed in distilled water, allowed to air-dry and placed in osmium tetroxide vapour for $\mathrm{I} h$ in a sealed glass Petri dish. Apart from generally increasing the specimen contrast the osmium is deposited in and blackens the sites of precipitated DAB polymer.

The sections were examined directly after osmication in a Philips EM200 or EM300 microscope at $60 \mathrm{kV}$. It was unnecessary to post-stain sections to increase contrast or detail. 
Control experiments. Method controls involved staining in which one of the stain components, i.e. anti-rabbit IgG, PAP or DAB, was omitted.

Specificity was controlled by substitution of the specific spore or vegetative cell antiserum with normal rabbit serum. Sections in which mixtures of vegetative cell and spore components were stained with either one or other of the specific antisera also served as inbuilt specificity controls.

Sensitivity testing involved incubation of the grids for a standard time in a range of antiserum dilutions. Our results were mainly qualitative, being quantitative only as regards the difficulty of demonstrating a particular antigen. For example, if in the bacterium an antigen is present in two localities in different quantities, it follows that whilst a given antiserum dilution may demonstrate antigen at one site, it would be necessary to increase the incubation time to demonstrate smaller quantities of antigen at the other. It was always ensured that increase in incubation time or antiserum concentration did not substantially alter the results presented. In general, an incubation time of 10 to $20 \mathrm{~min}$ at a dilution of specific antiserum of $\mathrm{I}: 50$ gave optimal results.

Preparation of antisera. The anti-rabbit serum was supplied by Wellcome Reagents Ltd, Beckenham, Kent, and was produced in donkeys. The anti-peroxidase serum necessary for the production of the PAP complex was produced in rabbits following the procedure described by Sternberger et al. (1970). The B. cereus vegetative cell and spore antisera were prepared in rabbits as previously described by Walker \& Batty (1965).

Preparation of the peroxidase-anti-peroxidase complex. PAP was prepared at the Wellcome Research Laboratories following the schedule outlined by Sternberger et al. (1970). Examination of negative-stained preparations of the material showed it to have all the morphological attributes described by these authors. It was frozen for storage in small stoppered vials containing $0.2 \mathrm{ml}$, using a solid $\mathrm{CO}_{2}$-acetone mixture, and was stored at $-20^{\circ} \mathrm{C}$. Frozen PAP was thawed at room temperature and diluted $\mathrm{I}: \mathrm{I} 0$ immediately before use. Any PAP not required for immediate use was stored at $4{ }^{\circ} \mathrm{C}$ in a light-tight container and used in later experiments. Batches of diluted PAP were not kept for more than 3 weeks.

\section{RESULTS}

Staining of germinating spores and sporulating cells with spore antiserum

Mixtures of spores and vegetative cells stained with spore antiserum showed deposits of stain along the exosporium only. No deposits of stain were seen on the vegetative cells or sporecoats (Fig. I).

Small amounts of deposits were demonstrated during forespore septum formation and increased as engulfment occurred (Figs. 2 and 3). Initially deposits were located in areas taken to be granules of poly-beta-hydroxybutyric acid (PBH) as well as in the immature forespores. No deposits were seen in control preparations (Fig. 4).

During maturation of the forespore, deposits could no longer be demonstrated within the cytoplasm of the forespore but increasing quantities of antigen were demonstrable in the cytoplasm of the vegetative cell (Figs. 5 and 6). During maturation of the spore there was evidence of condensation of the antigen to form the classical exosporium as evidenced by heavy deposition in this area (Figs. 7 and 8). 

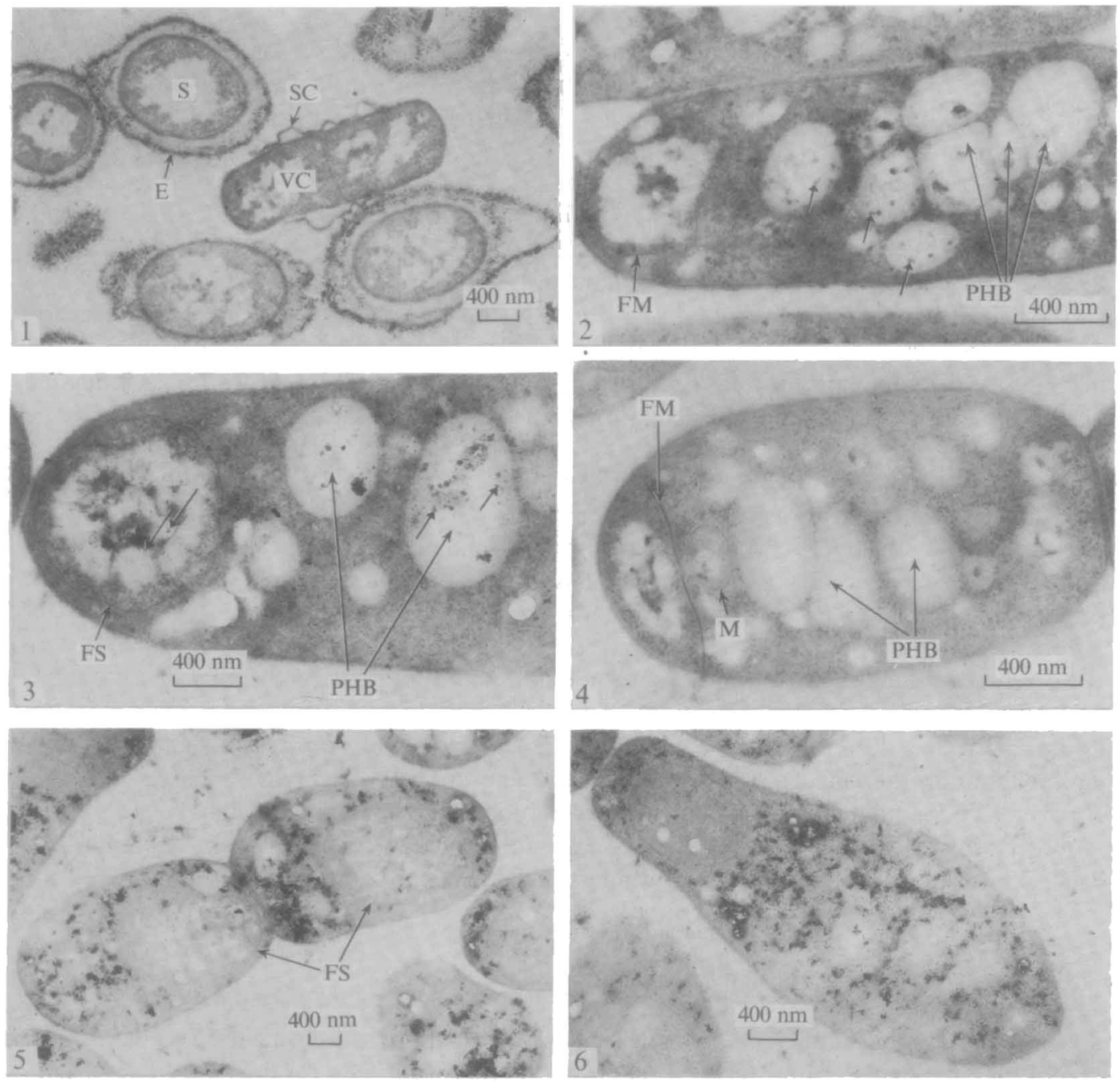

Fig. I. Section of a mixture of germinating spores (S) and vegetative cells (VC) stained with spore antiserum and PAP. Note staining of exosporium (E) but not of vegetative cell or sporecoat (SC).

Fig. 2. Section of sporulating cells of $B$. cereus showing forespore septum development (FM). Staining as in Fig. I. Note deposits (arrows) in PHB granules (PHB).

Fig. 3. Similarly stained section to that in Fig. 2, showing completed forespore (FS). Note deposits in both PHB granules and forespore cytoplasm (arrows).

Fig. 4. Section similar to Fig. 2. Control preparation in which antiserum has been substituted with normal rabbit serum. M, mesosome; FM, forespore membrane; PHB, PHB granules.

Fig. 5. Section of sporulating cells of B. cereus showing mature forespore (FS). Staining as in Fig. I. Note deposits in the sporangial cytoplasm but not in the forespore cytoplasm.

Fig. 6. Section of sporulating cell of $B$. cereus showing early cortical formation. Staining as in Fig. I. Note large amounts of deposits scattered throughout the cytoplasm. 

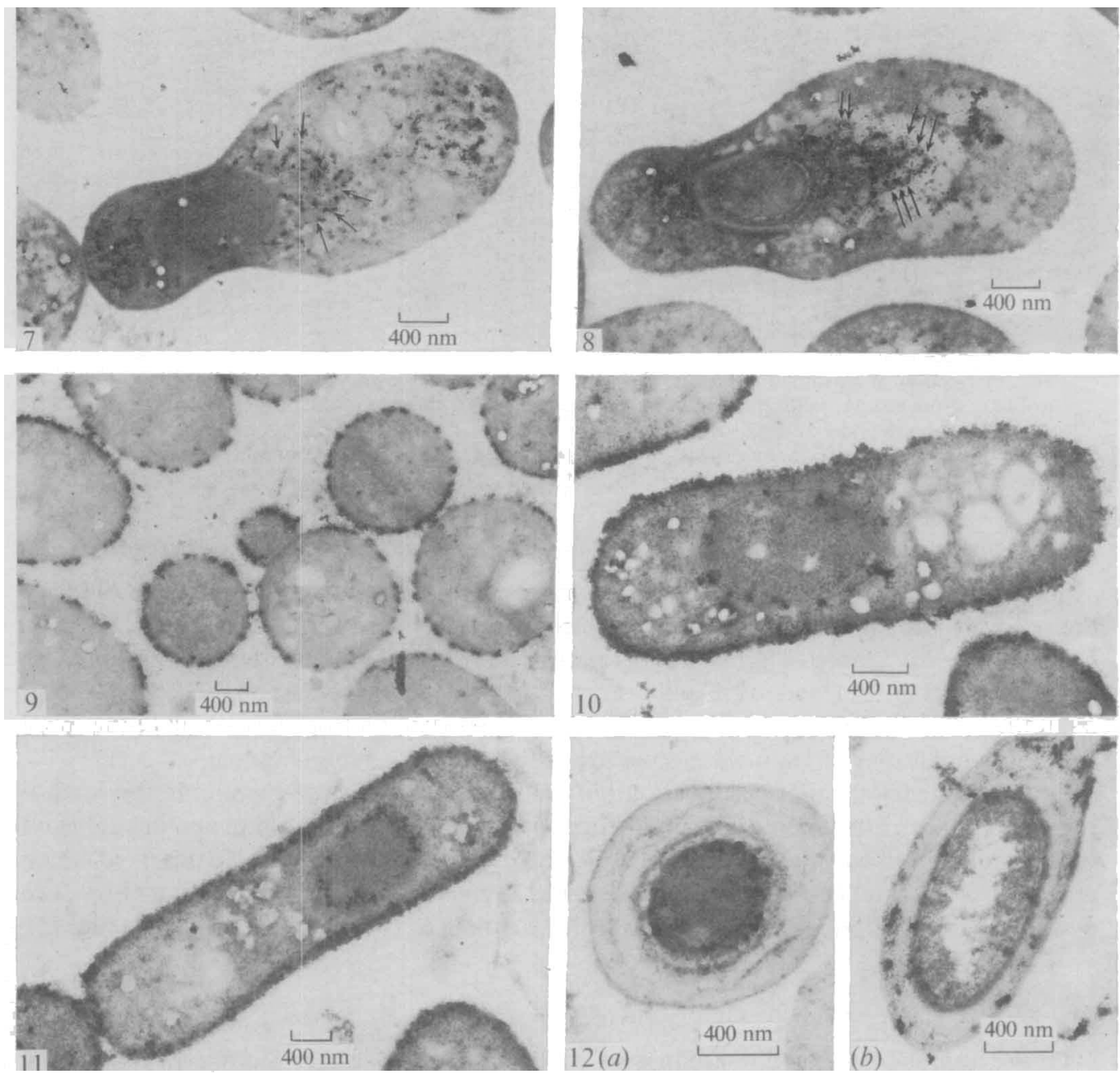

Fig. 7. Section of sporulating cell of B. cereus showing developing cortex. Staining as in Fig. I. Note condensation of deposits in the region of the developing exosporium (arrows).

Fig. 8. Section of sporulating cell of $B$. cereus showing coat development. Staining as in Fig. I. Note deposits around completed exosporium (arrows).

Fig. 9. Section of vegetative cell of $B$. cereus stained with vegetative antiserum and soluble PAP. Note deposits around the cell wall.

Fig. Io. Section of sporulating cell of $B$. cereus showing early cortex formation. Staining as in Fig. 9. Note deposits on the cell wall and scant deposits on the developing cortex.

Fig. I I. Section of sporulating cell of B. cereus showing mature cortex. Staining as in Fig. 9. Note deposits on cell wall and cortex.

Fig. 12. Section of germinating spores of $B$. cereus $(a)$ before and $(b)$ after swelling. Staining as in Fig. 9. Note deposits in cortical region in $(a)$, and scant deposits on primordial cell wall and large deposits trapped under the exosporium in $(b)$. 


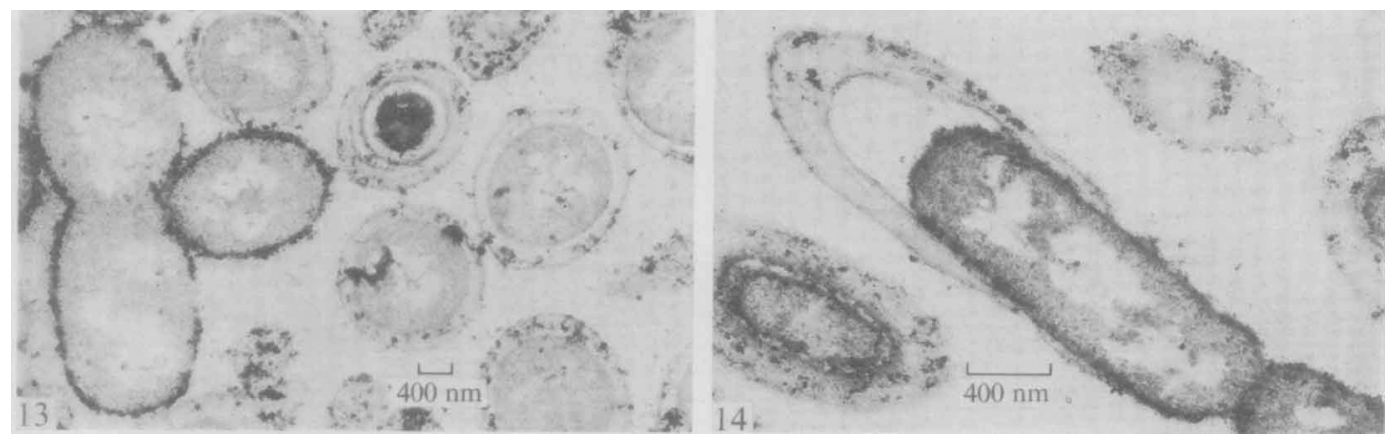

Fig. 13. Section of germinating spores of B. cereus showing outgrown vegetative cells. Staining as in Fig. 9. Note strong staining of the vegetative cell wall, poor staining of the primordial cell wall and deposits trapped under the exosporium.

Fig. 14. Section of germinating spore of B. cereus showing outgrowth. Staining as in Fig. 9. Note strong staining of cell wall and deposits trapped under the exosporium.

\section{Staining of sporulating cells and germinating spores with vegetative cell antiserum}

Sections of vegetative cells stained with homologous antiserum showed strong staining of the cell wall. This localization was interrupted at regular intervals by clear spaces (Fig. 9). During the early stages of forespore formation deposits in the forespore membrane area were sparse (Fig. IO) and were only seen after prolonged incubation, indicating small quantities of antigen relative to that present on the cell wall. During maturation of the spore increasing quantities of stain were observed in the cortical region (Fig. I I).

Spores immediately after germination but before swelling showed staining in the cortical region (Fig. 12a). During swelling and before outgrowth the antigenic sites demonstrable on the developing cell wall appeared scant (Fig. 1 $2 b$ ). Large deposits were also observed which appeared to be trapped between the developing vegetative cell and exosporium (Figs. I $2 b$ and I3). During outgrowth strong staining of the entire cell wall was demonstrated (Fig. 14).

\section{DISCUSSION}

Of the immunocytochemical techniques available (for review, see Sternberger, 1974) the PAP method is one that is extremely sensitive. Moriarty et al. (1973) claimed that it is 16000 to 100000 times more sensitive than radioimmunoassay, whilst Petrali et al. (1974) obtained both quantitative and qualitative results with it. It enabled us to locate bacterial antigens constantly and reliably in sections. As standard fixation and embedding techniques were used for all the specimens examined, it is assumed that true variations in the location and/or quantity of antigen were demonstrated.

By using ferritin- and enzyme-labelled antibodies, Walker \& Thomson (1972) showed that immunization of rabbits with autoclaved spore suspensions of $B$. cereus gave rise to antibody directed against the exosporium. The results obtained with the PAP method support this. Its detection in the very early stages of sporulation, i.e. during septum formation, correlates well with the observations of Aronson \& Fitz-James (I968) who, using pulse chase experiments, were able to demonstrate 'coat-protein' precursors at least several hours before morphologically-distinct coat structures. However, they made no distinction between exosporium and sporecoat, and it may be that their observations applied to exosporial protein only. Murrell, Ohye \& Gordon (1969) suggested that coat-protein is 
synthesized and deposited within the confines of the exosporium; this could only be elucidated with this technique by using antisera prepared against purified sporecoats.

The association of the antigenic sites within granules of PHB would support the theory postulated by Hanson, Peterson \& Yousten (I970) that PHB is probably degraded and the products serve as a carbon and energy source for 'endotrophic' sporulation.

The small amount of antigen transiently demonstrable in the forespore possibly represents material synthesized before total commitment to sporulation and, therefore, perhaps before total genetic repression. Antigen could no longer be demonstrated in the spore cytoplasm after engulfment and maturation but was confined to the sporangial cytoplasm as postulated by Ohye \& Murrell (1962). Although these materials have previously been called spore-protein precursors it is evident that they contain the antigenic determinants of the exosporium. These precursors must either be transported from their sites of synthesis to the site of exosporial deposition, or they are degraded and rebuilt nearer the actual site as sporulation proceeds. In this respect our results do not support the contention of Ohye \& Murrell (I973) that the outer forespore membrane could be associated with the formation of precursor material which upon entering the cytoplasm is self-assembled into the exosporium.

The staining of the cell wall peptidoglycan using the PAP technique gave results identical to those found by Walker \& Batty (1965), Walker et al. (1966, 1967) and Walker \& Thomson (1972) using an identical antiserum coupled directly to fluorescein, ferritin and acid phosphatase. The occurrence of clear areas devoid of staining may result from swelling of the organism with subsequent stretching of the cell wall during fixation and embedding, or polymerization of antigen during fixation; however, if antigen sites are able to move freely on a dynamic membrane surface, as Sternberger (1974) suggests, these areas might represent locations truly sparse in antigenic determinants.

Although biochemical differences have been reported between cortex and cell wall peptidoglycan (Tipper \& Gauthier, 1972), antigenically they appear to be identical, as during sporulation and immediately after germination (but before swelling) the whole cortical region stained uniformly. Once swelling had occurred, however, only small quantities of antigen could be demonstrated on the primordial cell wall, presumably due to spread of antigen over the increased surface area whilst large quantities were still trapped between this structure and the exosporium. The antigenic material present on the primordial cell wall may be true vegetative cell peptidoglycan incorporated and/or manufactured during sporulation, whilst that trapped under the exosporium may be cortical peptidoglycan broken down during germination.

Such results would agree with Hamilton \& Stubbs (1967) who showed that 60 to $70 \%$ of spore peptidoglycan was retained at least during the early stages of germination. Our results, however, do not support their argument that such material would be located in the exosporium.

With the outgrowth of the vegetative cell, strong staining of the vegetative cell wall was again observed but between this stage and the initial stages of germination we were unable to demonstrate large quantities of antigen on the developing cell wall (Fig. 13). According to Tipper \& Gauthier (1972) peptidoglycan precursors are synthesized in the cytoplasm, transferred to a membrane-bound carrier lipid, and polymerized, cross-linked and modified by hydrolysis on the external side of the membrane. Perhaps it is only in the final hydrolysis step that the antigenic determinants are exposed, which would account for the sudden transition from poor staining to strong staining.

Further studies using this technique to investigate other parameters of sporulation and germination are in progress. 


\section{REFERENCES}

Aronson, A. I. \& Fitz-James, P. C. (1968). Biosynthesis of bacterial sporecoats. Journal of Molecular Biology 33, 199-2 12.

Avrameas, S. (1969). Coupling of enzymes to proteins with glutaraldehyde. Use of the conjugates for the detection of antigens and antibodies. Immunochemistry 6, 43-5I.

AVrameas, S. \& Uriel, J. (I966). Méthode de marquage d'antigènes et d'anticorps avec des enzymes et son application en immunodiffusion. Comptes rendus hebdomadaire des séances de l'Academie de Sciences 262, 2543-2545.

Baillie, A., Thomson, R. O., Batty, I. \& Walker, P. D. (1967). Some preliminary observations on the location of esterases in Bacillus cereus. Journal of Applied Bacteriology 30, 31 2-31 6.

Hamilton, W. A. \& StubBs, J. M. (1967). Comparison of the germination and outgrowth of spores of Bacillus cereus and Bacillus polymyxa. Journal of General Microbiology 47, I2 I-I 29.

Hämmerling, U., AOKI, T., Harven, E., CoYse, E. A. \& Old, L. J. (1968). Use of hybrid antibodies with anti-yG and antiferritin specificities in locating cell surface antigens by electron microscopy. Journal of Experimental Medicine 128, 146I-1469.

hanson, R. S., Peterson, J. A. \& Yousten, A. A. (I970). Unique biochemical events in bacterial sporulation. Annual Review of Microbiology 24, 53-90.

Hinton, D. M., Petrali, J. P., Meyer, H. G. \& Sternberger, L. A. (1973). The unlabelled antibody enzyme method of immunohistochemistry. Molecular immunocytochemistry of antibodies on the erythrocyte surface. Journal of Histochemistry and Cytochemistry 21, 978-998.

KAWARAI, Y. \& NAKANE, P. K. (1970). Localisation of tissue antigens on ultrathin sections with peroxidaselabelled antibody method. Journal of Histochemistry and Cytochemistry 18, 16I-166.

Mason, T. E., Phifer, R. F., Spicer, S. S., Swallow, R. A. \& Dreskin, R. B. (1969). An immunoglobulinenzyme bridge method for localising tissue antigens. Journal of Histochemistry and Cytochemistry $\mathbf{1 7}$, 563-569.

Moriarty, G. C. \& Halmi, N. S. (1972). Electron microscopic study of the adrenocorticotropin producing cell with the use of unlabelled antibody and the soluble peroxidase-anti-peroxidase complex. Journal of Histochemistry and Cytochemistry 20, 590-603.

Moriarty, G. C., Moriarty, M. \& STernberger, L. A. (1973). Ultrastructural immunocytochemistry with unlabelled antibodies and the peroxidase-anti-peroxidase complex. A technique more sensitive than radioimmunoassay. Journal of Histochemistry and Cytochemistry 21, 825-833.

Múrrell, W. G., OHYE, D. F. \& Gordon, R. A. (1969). Cytological and chemical structure of the spore. In Spores, vol. 4, pp. I-19. Edited by L. L. Campbell. Washington: American Society for Microbiology.

NAKANe, P. \& Pierce, G. (1967a). Enzyme labelled antibodies preparation and application for the localisation of antigens. Journal of Histochemistry and Cytochemistry r4, 929-93I.

Nakane, P. \& Pierce, G. (1967 b). Enzyme labelled antibodies for the light and electron microscopic localisation of tissue antigens. Journal of Cell Biology 33, 307-310.

Ohye, D. \& Murrell, W. G. (1962). Formation and structure of the spore of Bacillus coagulans. Journal of Cell Biology 14, I I I-123.

OHYE, D. \& MURRell, W. G. (1973). Exosporium and sporecoat formation in Bacillus cereus. Journal of Bacteriology II5, I $179-1190$.

Petrali, J. P., Hinton, D. M., Moriarty, G. C. \& Sternberger, L. A. (1974). The unlabelled antibody enzyme method of immunohistochemistry. Quantitative comparison of sensitivities with and without peroxidase-anti-peroxidase complex. Journal of Histochemistry and Cytochemistry 22, 782-801.

SternberGer, L. A. (1974). Immunocytochemistry. Englewood Cliffs, New Jersey: Prentice-Hall.

Sternberger, L. A. \& Cuculis, J. J. (1969). Method for enzymatic intensification of the immunocytochemical reaction without the use of labelled antibodies. Journal of Histochemistry and Cytochemistry I7, 190.

Sternberger, L. A., Hardy, P. H., Jun., Cuculis, J. J. \& Meyer, H. G. (1970). The unlabelled antibody enzyme method of immunohistochemistry. Preparation and properties of soluble antigen-antibody complex (horseradish peroxidase-antihorseradish peroxidase) and its use in identification of spirochetes. Journal of Histochemistry and Cytochemistry 18, 31 5-333.

TipPer, D. J. \& Gauthier, J. J. (1972). Structure of the bacterial endospore. In Spores, vol. 5, pp. 3-I 2. Edited by H. O. Halvorson, R. Hanson and L. L. Campbell. Washington: American Society for Microbiology.

WALKER, P. D. (I969). The location of chemical components on ultrathin sections of Bacillus cereus embedded in glycol methacrylate. Journal of Applied Bacteriology 32, 463-467. 
Walker, P. D., Baillie, A., Thomson, R. O. \& Batty, I. (I966). The use of ferritin labelled antibodies in the location of spore and vegetative antigens of Bacillus cereus. Journal of Applied Bacteriology 29, 5I 25 I 8.

WALKER, P. D. \& BATTY, I. (I964). Fluorescent studies in the genus Clostridium. I. The location of antigens on the surface of Clostridium sporogenes during sporulation and germination. Journal of Applied Bacteriology 27, 137-1 39 .

WALKER, P. D. \& BATTY, I. (1965). Surface antigenic changes in Bacillus cereus during germination and sporulation as shown by fluorescent staining. Journal of Applied Bacteriology 28, 194-196.

WALKER, P. D. \& Thomson, R. O. (I972). Immunology of spores and sporeforms. In Spores, vol 5, pp. 32 I337. Edited by H. O. Halvorson, R. Hanson and L. L. Campbell. Washington: American Society for Microbiology.

Walker, P. D., Thomson, R. O. \& Baillie, A. (1967). Use of ferritin labelled antibodies in the location of spore and vegetative antigens of Bacillus subtilis. Journal of Applied Bacteriology 30, 3I 7-320.

WAlker, P. D., Thomson, R. O. \& ShORT, J. A. (I971). Location of chemical components on ultrathin sections of bacteria. Spore Research I971, pp. 202-209. Edited by A. N. Barker, G. W. Gould and J. Wolf. London: Academic Press. 